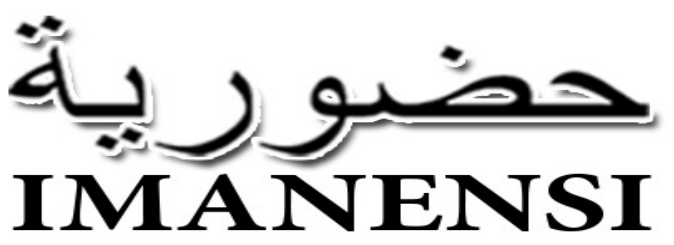

Jurnal Ekonomi, Manajemen, dan Akuntansi Islam

Vol 5, No 2, September 2020, Hlmn. 104-115

\title{
Kinerja keuangan rumah sakit syariah: pendekatan Maqashid Syariah Concordance (MSC)
}

\section{Fadjar Setiyo Anggraenia,1,*}

a Rumah Sakit Islam Sultan Agung, Jl.Raya Kaligawe Km.4 Semarang, 50211, Indonesia.

1FSA-kampus@windowslive.com*

* correspondence author

10.34202/imanensi.5.2.2020.104-115.

\section{Abstrak}

Tujuan dilakukan penelitian ini adalah membantu manajemen rumah sakit Sultan Agung mengukur kinerja dengan Maqashid Syariah Concordance (MSC). Jenis penelitian kuantitatif dengan menganalisis laporan keuangan rumah sakit syariah selama 2015 hingga 2019, data dihitung dengan membuat indeks sesuai model Maqashid Syariah Concordance (MSC). Hasil penelitian menunjukan porsi biaya dakwah dan sosial (daksos) sangat baik jika dibandingkan dengan nilai zakat mal, peran komite syariah sudah sesuai dengan fungsinya, kerjasama rumah sakit Sultan Agung dengan bank syariah memiliki proporsi lebih kecil dibandingkan kerja sama dengan bank konvensional, selanjutnya ZIS dan treatment terhadap pasien tidak mampu belum terdistribusi secara periodik.
\end{abstract}

Kata Kunci: Rasio Kinerja; Keadilan; Zakat; Komite Syariah; Pasien.

\begin{abstract}
The purpose of this research is to help the management of the Sultan Agung hospital to measure performance with Maqashid Syariah Concordance (MSC). This type of quantitative research analyzes the financial reports of Islamic hospitals from 2015 to 2019, the data is calculated by making an index according to the Maqashid Syariah Concordance (MSC) model. The results showed that the portion of dakwah and social costs (daksos) was very good when compared to the value of zakat mal, the role of the sharia committee was in accordance with its function, the cooperation between Sultan Agung hospital and Islamic banks had a smaller proportion compared to cooperation with conventional banks, then ZIS and treatment of incapacitated patients has not been distributed periodically.
\end{abstract}

Keywords: Performance Ratio; Justice; Zakat; Sharia Committee; Patient.
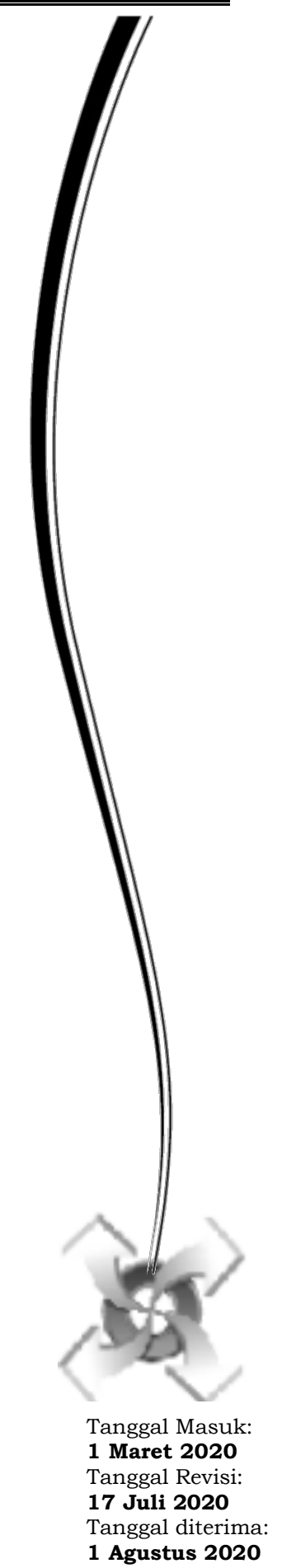


\section{PENDAhUluan}

Tujuan dari ekonomi Islam adalah pencapaian maqashid syariah melalui terwujudnya keadilan dan keseimbangan di dalam masyarakat. Maqashid syariah inilah yang menjadi 'ruh' dalam praktik bermuamalah. Geliat penerapan prinsip syariah dalam bermuamalah di Indonesia sendiri mulai hadir pada tahun 1980 dan berlanjut dengan lahirnya lembaga keuangan yang pertama berdasarkan prinsip syariah pada tahun 1992, yaitu Bank Muamalat Indonesia (BMI). Indonesia memiliki potensi dan peluang yang besar untuk perkembangan industri perbankan syariah kedepannya, mengingat Indonesia adalah negara dengan populasi penduduk muslim terbesar di dunia (Alhamid, 2019).

Kepercayaan publik terhadap pelayanan syariah saat ini sudah demikian meningkat. Bahkan dewasa ini, telah mengarah kepada gaya hidup (lifestyle). Euforia ini terjadi tak hanya pada pemilihan produk jasa perbankan, akan tetapi di hampir semua sisi kehidupan masyarakat, termasuk dalam penggunaan jasa pelayanan kesehatan. Munculnya rumah sakit syariah pertama kali, ditandai dengan terbitnya fatwa DSN-MUI (Dewan Syariah Nasional-Majelis Ulama Indonesia) nomor 107/DSN-MUI/X/2016 tentang Pedoman Penyelenggaraan Rumah Sakit Syariah (selanjutnya disebut Fatwa Rumah Sakit Syariah) pada tanggal 1 Oktober 2016. Selanjutnya, ditetapkannya Rumah Sakit Islam Sultan Agung, menjadi momentum penting dalam sejarah syariah perumahsakitan. Penetapan tersebut telah melalui serangkaian penilaian standar syariah berupa Standar Akreditasi Rumah Sakit Syariah yang diterbitkan oleh Majelis Upaya Kesehatan Islam Indonesia (MUKISI).

Saat ini Indonesia sebagai negara dengan penduduk mayoritas muslim (87,2 persen) memiliki potensi yang sangat besar dalam upaya pengembangan pelayanan kesehatan syariah. Keberadaan rumah sakit yang berbasis agama Islam memang sudah lama ada, akan tetapi belum memiliki standar acuan dan lembaga yang melegitimasi. Penerapan nilai-nilai Islam perlu dikukuhkan dengan sertifikasi rumah sakit syariah. Hal tersebut penting dilakukan untuk memberikan keyakinkan bagi pasien yang beragama Islam bahwasannya pelayanan yang diberikan oleh rumah sakit sudah sesuai dengan nilai-nilai Islam, sehingga tidak tidak ada keraguan baginya menerima pelayanan. Dari laman https://www.madaninews.id dalam tulisan Abi Abdul Jabbar (2020) dikatakan bahwa pada tahun 2019 dari total 2.900 rumah sakit di Indonesia, 500 di antaranya adalah rumah sakit Islam dan dinaungi oleh lembaga Islam. Akan tetapi sampai saat ini baru sekitar 22 rumah sakit yang tersertifikasi syariah, terdiri dari 18 rumah sakit Islam, dan empat rumah sakit milik pemerintah. Sementara ada setidaknya 65 rumah sakit yang sedang dalam proses pendampingan untuk mendapatkan sertifikasi syariah, baik dari rumah sakit Islam, maupun rumah sakit milik pemerintah. Ditargetkan pada tahun 2020 akan ada 100 rumah sakit yang tersertifikasi syariah. Perkembangan ini cukup menggembirakan, akan tetapi hal yang cukup mengganggu dalam implementasi standar syariah manajemen keuangannya adalah bahwa rumah sakit syariah masih menggunakan alat ukur konvensional untuk kinerja keuangannya.

Dalam mengukur kinerja keuangannya, rumah sakit syariah masih mengandalkan pada rasio keuangan yang biasa digunakan oleh perusahaan umum seperti rasio profitabilitas, likuiditas, solvabilitas, dan beberapa rasio keuangan lain yang dianggap mampu memberikan informasi kepada manajemen untuk digunakan dalam pertimbangan pengambilan keputusan. Oleh karena itu, apabila pengelolaan keuangan rumah sakit tidak berjalan 
dengan baik, maka kebutuhan akan daya dukung pelayanan kesehatan akan terganggu (Susanti dan Murnita, 2017). Salah satu solusi yang ditawarkan Islam, yaitu melalui pendekatan maqashid syariah dalam istimbath hukum. Di mana pendekatan tersebut mempertimbangkan realitas atau situasi praktikal dalam hubungannya dengan tujuan akhir (maqashid) dan nilai-nilai mulia syariat, serta aturan masyarakat dan peradaban (Sulistiadi dan Rahayu. 2016)

Penelitian mengenai penilaian kinerja keuangan rumah sakit syariah dengan menggunakan Maqashid Syariah Concordance (MSC) belum pernah ditemukan sebelumnya. Dari mesin pencarian Google atau Google Scholar, ditemukan berbagai tulisan terkait dengan penggunaan Maqashid Syariah Index yang digunakan dalam penilaian kinerja perbankan syariah, akan tetapi sama sekali tidak ditemukan tools tersebut digunakan untuk mengukur kinerja keuangan rumah sakit. Oleh karenanya, dalam penelitian ini, digunakan modifikasi alat ukur Maqashid Syariah Concordance (MSC) yang khusus digunakan untuk mengukur kinerja keuangan rumah sakit syariah.

\section{METODE}

Penelitian ini dilakukan pada Rumah Sakit Islam Sultan Agung (RSISA) di Kota Semarang. Dalam penelitian ini tidak akan dijelaskan variabel-variabel seperti pada penelitian regresi namun akan mendeskripsikan nilai melalui pengukuran analisis laporan keuangan melalui pendekatan maqashid syariah Concordance, yaitu ukuran kinerja yang didasarkan pada kerangka maqashid syariah. Rasio-rasio yang digunakan sebagaimana yang dipaparkan pada tabel 2. Rasio kinerja yang dipilih tersebut dirumuskan dari standar-standar yang ada di dalam Buku Standar Akreditasi Rumah Sakit Syariah, yang digunakan dalam penilaian akreditasi rumah sakit syariah oleh DSN-MUI. Rumusan ini terinspirasi dari tools yang digunakan oleh Mohammed dan Dzuljastri (2008).

Perbedaan penelitian ini dengan penelitian sebelumnya adalah, karena dimensi dan indikator pengukuran diambil dari Buku Standar Akreditasi Rumah Sakit Syariah, maka bisa dipastikan bahwa unsur syariahnya tidak memerlukan pembahasan. Sedangkan untuk menentukan nilai rasio dari masing-masing dimensi dan indikator syariah tersebut, peneliti menyebarkan kuesioner kepada 73 orang responden. dengan distribusi $52.1 \%$ staf rumah sakit, 20.5\% pemerhati perkembangan rumah sakit syariah, 16.4\% pengguna produk pelayanan kesehatan di rumah sakit Islam/Syariah, dan $11 \%$ sisanya adalah pengguna produk layanan kesehatan selain RS Islam/Syariah. Skor yang didapat dari hasil penilaian dan tujuh Indikator rasio disajikan dalam Tabel 10 dan Tabel 11 di lampiran.

\section{HASIL DAN PEMBAHASAN}

\subsection{Rencana Kerja Anggaran yang Disusun, Memenuhi Prinsip Keadilan}

Prinsip keadilan yang dimaksud di dalam penyusunan anggaran, menurut paparan yang disampaikan oleh Masyhudi (2019) dilakukan dengan mempertimbangkan alokasi anggaran atas kebutuhan pengelolaan operasional rumah sakit dan kebutuhan dakwah kepada masyarakat. Kemudian, mencermati firman Allah dalam Q.S. Al-Maidah, (5) ayat 6, QS. A1Mukminun (20) ayat 6, dan QS. Al-An'am (6) ayat 12 yang menyatakan bahwa seseorang yang beruntung memperolehnya pada hakikatnya hanya menerima titipan sebagai amanat untuk disalurkan dan dibelanjakan sesuai dengan kehendak pemilik sebenarnya (Allah SWT). Firman Allah yang lain; "Dan pada harta-harta mereka ada hak untuk orang miskin yang meminta dan orang 
miskin yang tidak mendapat bahagian" (Q.S. adz-Dzariyaat, 51: 19), sesungguhnya hal tersebut mengindikasikan bahwa di dalam sisa usaha yang diperoleh seseorang, ada bagian dari orang miskin yang yarus didistribusikan melalui zakat.

Oleh karena rumah sakit tidak menghitung zakat maka logis jika lembaga ini mengalokasikan hartanya untuk dana dakwah dan sosial setara dengan nilai zakat mal $2.5 \%$ dari sisa usaha. Dengan demikian, bisa dikatakan bahwa untuk setiap rasio di bawah nilai tersebut, kinerja masuk kategori tidak sehat, dan sebaliknya, jika nilainya sama dengan atau lebih dari standar, maka rumah sakit syariah masuk kategori sehat. Anggaran biaya dakwah dihitung dari jumlah biaya kemitraan, biaya untuk dana sosial dan beban penghapusan piutang non relasi. Data untuk anggaran biaya dakwah dan total biaya yang dianggarkan selama kurun waktu 2015 s.d. 2019 disajikan dalam Tabel 1.

Tabel 1. Rasio Keadilan Anggaran

\begin{tabular}{cccc}
\hline Tahun & $\begin{array}{c}\text { Anggaran } \\
\text { Dakwah }\end{array}$ & SUd & Rasio \\
\hline 2015 & $1,991,485,000$ & 20.476 .342 .072 & $9,73 \%$ \\
2016 & $2,833,776,301$ & 27.806 .036 .182 & $10,19 \%$ \\
2017 & $4,193,121,756$ & 49.531 .397 .518 & $8,47 \%$ \\
2018 & $3,967,186,068$ & 54.663 .605 .125 & $7,26 \%$ \\
2019 & $1,949,724,420$ & $54,663,605,125$ & $3,57 \%$ \\
\hline
\end{tabular}

Hasil perhitungan rasio di atas menunjukkan nilai keadilan anggaran rumah sakit syariah menunjukkan angka rasio dari tahun 2015 hingga 2019 menunjukkan nilai di atas $2.5 \%$. Hal ini bisa dikategorikan sebagai suatu amalan yang ihsan. Namun demikian perlu mendapatkan perhatian karena nilainya semakin menurun.

\subsection{Tarif Rumah Sakit Bersifat Adil bagi Pasien, Dokter dan Rumah Sakit}

Firman Allah dalam surat al-Nisa (4):135: "Wahai orang-orang yang beriman, jadilah kamu penegak al-qisth (keadilan), menjadi saksi karena Allah, walaupun terhadap dirimu sendiri..." Tafsir Quraish Shihab menyatakan bahwasannya keadilan adalah sistem kehidupan yang tidak dipertentangkan lagi. Konsep keadilan melibatkan apa yang setimpal, setimbang, dan benar-benar sepadan bagi tiap-tiap individu (Almubarok, 2018). Data untuk komplain atas tarif rumah sakit oleh dokter maupun pasien, dan jumlah item tarif produk selama kurun waktu 2015 s.d. 2019 perhitungan rasionya disajikan dalam Tabel 2.

Tabel 2. Rasio Keadilan Tarif

\begin{tabular}{cccc}
\hline Tahun & \multicolumn{2}{c}{ Komplain oleh } & Rasio \\
& Dokter & Pasien & \\
\hline 2015 & $(3 \times 6) / 119$ & 0 & $15,13 \%$ \\
2016 & $(0 \times 6) / 128$ & 0 & $0,00 \%$ \\
2017 & $(2 \times 6) / 128$ & 0 & $9,38 \%$ \\
2018 & $(5 \times 6) / 130$ & 0 & $23,08 \%$ \\
2019 & $(2 \times 6) / 130$ & 0 & $9,23 \%$ \\
\hline
\end{tabular}

Rasio komplain terhadap tarif masih dalam batas kewajaran. Selama kurun waktu 2015 hingga 2019 rasio komplain bervariasi, yang tertinggi ada 
di tahun 2018 di mana terdapat 5 orang dokter dari SMF yang berbeda meminta penyesuaian tarif. Namun dari data Bidang Humas dan Kemitraan sejak 2015, tidak ditemukan komplain terhadap tarif dari pasien yang mendapatkan pelayanan kesehatan di rumah sakit.

\subsection{Rekomendasi dari Komite Syariah terhadap Kebijakan yang Diambil oleh Rumah Sakit}

Dari Al Qur'an Surat An-Nahl ayat 43 menerangkan; "Dan Kami tidak mengutus sebelum kamu, kecuali orang-orang lelaki yang Kami beri wahyu kepada mereka; maka bertanyalah kepada orang yang mempunyai pengetahuan jika kamu tidak mengetahui". Komite Syariah memiliki tugas untuk menilai, mengawasi, serta memberikan rekomendasi terhadap kebijakan dan tata kelola pelayanan kesehatan di rumah sakit sesuai prinsip syariah. Dengan demikian, ada jaminan bahwa nilai-nilai Islam dalam pelayanan kesehatan dapat terimplementasi di setiap unit kerja di rumah sakit.

Seberapa tinggi keterlibatan Komite Syariah dalam pengambilan keputusan dan perumusan kebijakan rumah sakit dalam bidang keuangan dihitung dari jumlah rekomendasi Komite Syariah (RKS) yang diterbitkan untuk jumlah surat permohonan yang dilayangkan oleh bidang keuangan kepada Komite Syariah selama 1 periode. Data untuk jumlah rekomendasi Komite Syariah serta jumlah regulasi dan kasus terkait praktik keuangan di rumah sakit selama kurun waktu 2015 s.d. 2019 perhitungan rasionya disajikan dalam tabel 3.

Tabel 3. Rasio Keterlibatan Komite Syariah

\begin{tabular}{cccc}
\hline Tahun & Rekomendasi & $\begin{array}{c}\text { Jumlah } \\
\text { Surat }\end{array}$ & Rasio \\
\hline $\mathbf{2 0 1 5}$ & 1 & 1 & $100 \%$ \\
$\mathbf{2 0 1 6}$ & 2 & 2 & $100 \%$ \\
$\mathbf{2 0 1 7}$ & 1 & 1 & $100 \%$ \\
$\mathbf{2 0 1 8}$ & 2 & 2 & $100 \%$ \\
$\mathbf{2 0 1 9}$ & 1 & 1 & $100 \%$ \\
\hline
\end{tabular}

Hasil perhitungan rasio pada tabel 3 memperlihatkan bahwa dari waktu ke waktu, Komite Syariah di rumah sakit syariah selalu memberikan kontribusi peran dalam menjaga implementasi syariah, utamanya di bidang keuangan.

\subsection{Zakat Karyawan}

Zakat merupakan rukun Islam yang ketiga, yang menjadi kewajiban bagi setiap muslim yang memiliki kemampuan. Ditinjau dari segi bahasa, zakat memiliki banyak arti, yaitu al-barakatu yang mempunyai arti keberkahan, ath-thaharatu yang memiliki arti kesucian, al-namaa yang mempunyai arti pertumbuhan dan perkembangan, dan ash-shalahu yang memiliki arti keberesan (Hafidhuddin. 2002). Islam dibangun di atas lima hal: kesaksian sesungguhnya tiada Tuhan selain Allah dan sesungguhnya Muhammad utusan Allah, melaksanakan shalat, membayar zakat, haji, dan puasa Ramadhan." (HR Bukhari - Muslim).

Pemungutan zakat karyawan dimaksudkan sebagai proses pembelajaran bagi karyawan mengenai kewajiban, dan manfaat dari zakat, sehingga mengenai besarnya nishab masing-masing karyawan, diabaikan. Rasio zakat karyawan dihitung dari jumlah potongan zakat karyawan dan professional dokter dibagi dengan total biaya yang dikeluarkan untuk karyawan dan 
professional. Total biaya tenaga kerja dihitung dari komponen biaya yang diterima dalam bentuk uang, meliputi; jasa medis, gaji, tunjangan, insentif, jasa pelayanan, lembur dll, yang diterimakan dalam bentuk uang. Jumlah potongan zakat karyawan dan zakat profesi serta total biaya tenaga kerja masing-masing periode dari 2015 s.d. 2019 (Tabel 4).

Tabel 4. Rasio Zakat Karyawan

\begin{tabular}{lcrrr}
\hline Tahun & $\begin{array}{c}\text { Potongan } \\
\text { Zakat }\end{array}$ & \multicolumn{1}{c}{$\begin{array}{c}\text { Zakat } \\
\text { Profesi }\end{array}$} & \multicolumn{1}{c}{ Total BTK } & Rasio \\
\hline $\mathbf{2 0 1 5}$ & $288,282,848$ & $19,250,000$ & $84,191,150,928$ & $0.37 \%$ \\
$\mathbf{2 0 1 6}$ & $371,811,395$ & $3,047,708$ & $103,409,083,300$ & $0.36 \%$ \\
$\mathbf{2 0 1 7}$ & $456,504,741$ & $7,065,735$ & $118,338,814,910$ & $0.39 \%$ \\
$\mathbf{2 0 1 8}$ & $532,286,815$ & $10,000,000$ & $125,627,524,213$ & $0.43 \%$ \\
$\mathbf{2 0 1 9}$ & $665,086,308$ & $5,000,000$ & $130,868,181,749$ & $0.51 \%$ \\
\hline
\end{tabular}

Angka rasio selama kurun waktu 5 tahun berada jauh di bawah nilai perhitungan zakat yang semestinya. Jika ditelusur lebih lanjut, hal ini terjadi karena kebijakan dari manajemen hanya memotong 2,5\% zakat karyawan dari gaji pokok, sementara untuk penerimaan kesejahteraan lain dalam bentuk uang belum dikenakan zakat. Mengenai zakat profesi, di dalam Akad Ijarah antara rumah sakit dengan dokter terdapat satu klausul di mana rumah sakit menyediakan unit pengumpul zakat (UPZ) dan dokter dihimbau untuk dapat menyalurkan ZIS-nya melalui UPZ dimaksud. Namun demikian nampaknya esensi dari himbauan tersebut belum cukup mengena.

\subsection{Saldo Dana ZIS}

Dana ZIS yang telah dipungut dari karyawan dan profesional akan disalurkan kepada delapan golongan (asnaf) sesuai ketentuan yang sudah difirmankan oleh Allah dalam QS. At-Taubah ayat 60.

"Sesungguhnya zakat-zakat itu, hanyalah untuk orang-orang fakir, orang-orang miskin, pengurus-pengurus zakat, para mu'allaf yang dibujuk hatinya, untuk (memerdekakan) budak, orang-orang yang berhutang, untuk jalan Allah dan untuk mereka yuang sedang dalam perjalanan, sebagai suatu ketetapan yang diwajibkan Allah, dan Allah Maha Mengetahui lagi Maha Bijaksana”.

Landasan normatif mengenai pendistribusian zakat mengacu pada makna haul (satu tahun), di mana pengelola zakat memiliki kewajiban untuk dapat mendistribusikan zakat yang dititipkan muzaki padanya sebelum satu haul, atau sebelum masa penghitungan dan pembayaran zakat berikutnya. Hal ini diperkuat dengan terbitnya Peraturan Pemerintah nomor 20 tahun 2014 yang mengatur struktur, tanggung jawab, dan persyaratan organisasi pengelola zakat, di mana pada pasal 73 PP tersebut disampaikan mengenai kewajiban Lembaga Amil Zakat (LAZ) untuk menyampaikan laporan pelaksanaan pengelolaan zakat, infak dan sedekah serta dana sosial keagamaan yang dikelolanya kepada BAZNAS dan Pemerintah Daerah setiap 6 bulan dan akhir tahun.

Mengacu pada landasan normatif dan PP di atas, maka dapat dimaknai bahwa setiap akhir haul, zakat yang dikelola sudah harus habis didistribusikan kepada golongan yang berhak. Dengan demikian, rasio Saldo Dana ZIS dihitung dari jumlah saldo mengendap pada rekening ZIS 
dibandingkan dengan total penerimaan ZIS selama satu periode. Data untuk saldo rekening zakat setiap periode dan total penerimaan zakat profesi serta total biaya tenaga kerja untuk masing-masing periode selama kurun waktu 2015 s.d. 2019 (tabel 5).

Tabel 5. Rasio Saldo Dana ZIS

\begin{tabular}{lrrr}
\hline Tahun & $\begin{array}{c}\text { Saldo rekening } \\
\text { ZIS }\end{array}$ & $\begin{array}{c}\text { Total Penerimaan } \\
\text { ZIS }\end{array}$ & Rasio \\
\hline 2015 & - & $307,532,848$ & $0.00 \%$ \\
2016 & - & $374,859,103$ & $0.00 \%$ \\
2017 & $1,209,734,002$ & $1,673,304,476$ & $72.30 \%$ \\
2018 & $2,651,854$ & $1,752,020,817$ & $0.15 \%$ \\
2019 & $2,651,852$ & $670,086,308$ & $0.40 \%$ \\
\hline
\end{tabular}

Data saldo ZIS yang diukur dalam penelitian ini adalah saldo yang ada di rumah sakit, bukan di Unit Pengumpul Zakat. Hasil penilaian rasio Saldo dana zakat dalam penelitian ini berpedoman bahwa semakin kecil nilai saldo mengendap pada rekening ZIS, maka semakin baik nilai kesehatan rumah sakit syariah, karena hal ini mengindikasikan penerimaan ZIS segera didistribusikan kepada golongan yang berhak sebagaimana landasan normatif yang sudah disampaikan sebelumnya. Dari tabel perhitungan, dapat dilihat bahwa secara umum, nilai saldo di bawah 1\%, hanya pada tahun 2017 saldo cukup tinggi, yang terkoreksi dengan distribusi di tahun 2018, dan stagnan di tahun 2019.

\subsection{Kerja Sama dengan Bank Syariah}

Dalam Fatwa Dewan Syariah Nasional - Majelis Ulama Indonesia (DSNMUI) Nomor 107/DSN-MUIIX/2016 tentang Pedoman Penyelenggaraan Rumah Sakit Berdasarkan Prinsip Syariah, diktum ketujuh mengenai ketentuan terkait Penempatan, Penggunaan dan Pengembangan Dana Rumah Sakit, ditegaskan bahwa rumah sakit wajib menggunakan jasa Lembaga Keuangan Syariah dalam upaya penyelenggaraan rumah sakit, baik bank, asuransi, lembaga pembiayaan, lembaga penjaminan, maupun dana pensiun. Dengan demikian, rumah sakit syariah wajib bekerja sama dengan bank syariah, sehingga rasionya dihitung berdasarkan jumlah LKS yang bekerja sama dibanding jumlah total LK yang bekerja sama.

Data untuk Jumlah Lembaga Keuangan Syariah yang bekerja sama dengan rumah sakit, dan jumlah bank, asuransi, lembaga pembiayaan, lembaga penjaminan, maupun dana pensiun yang bekerja sama selama kurun waktu 2015 s.d. 2019 (tabel 6).

Tabel 6. Rasio Kerja sama dengan Bank Syariah

\begin{tabular}{cccc}
\hline Tahun & $\begin{array}{c}\text { Bank } \\
\text { Syariah }\end{array}$ & $\begin{array}{c}\text { Jumlah LK } \\
\text { Kerjasama }\end{array}$ & Rasio \\
\hline 2015 & 3 & 10 & 0.30 \\
2016 & 5 & 10 & 0.50 \\
2017 & 5 & 10 & 0.50 \\
2018 & 5 & 9 & 0.56 \\
2019 & 5 & 9 & 0.56
\end{tabular}

Hasil perhitungan nilai rasio kerjasama dengan bank syariah seperti yang tersaji dalam tabel di atas, menunjukkan adanya upaya dari rumah sakit untuk mengimplementasikan fatwa dari DSN-MUI. Hal ini terlihat dari 
nilai rasio yang semakin naik yang didukung oleh penambahan jumlah kerja sama dengan bank syariah (sejak 2016) atau mengakhiri kerja sama dengan bank konvensional (pada 2018) dan kedua hal ini bisa terus dilakukan hingga rasio mencapai 1.00 atau $100 \%$.

\subsection{Treatment Terhadap Pembayaran Pasien yang Tidak Mampu Membayar}

Dari hadits riwayat At-Tirmidzi 1078 dan Ibnu Majah 2413, dari Abu Hurairah Radhiyallahu 'anhu. Dishahihkan oleh Syaikh Al-Albani di dalam Shahihul Jami' 6779, bahwa Rasulullah SAW bersabda; "Jiwa (ruh) seorang mukmin tergantung karena hutangnya, sampai terlunasi”. Hal ini menjadi dasar bagi rumah sakit syariah untuk memprioritaskan penyelesaian piutang atas pasien tidak mampu yang meninggal. Selain itu pasien lain yang masuk ke dalam golongan 8 asnaf sebagaimana disampaikan di dalam QS. AtTaubah ayat 60 juga menjadi fokus penyelesaian berdasarkan skala prioritas yang dibuat oleh manajemen.

Mengacu pada uraian di atas, maka rasio dari treatment terhadap pembayaran pasien yang tidak mampu membayar dihitung dari membandingan jumlah subsidi pasien tidak mampu/total biaya pelayanan untuk pasien tidak mampu selama satu periode. Data untuk jumlah subsidi kepada pasien tidak mampu dan total biaya yang dikeluarkan rumah sakit untuk pelayanan kesehatan bagi pasien tidak mampu pada masing-masing periode selama kurun waktu 2015 s.d. 2019 (tabel 7).

Tabel 7. Rasio Treatment Pasien Tidak Mampu

\begin{tabular}{lrrr}
\hline Tahun & $\begin{array}{c}\text { Subsidi Pasien } \\
\text { TM }\end{array}$ & $\begin{array}{c}\text { Biaya untuk } \\
\text { Pasien TM }\end{array}$ & \multicolumn{1}{c}{ Rasio } \\
\hline 2015 & $25,466,800$ & $35,628,940$ & $71.48 \%$ \\
2016 & $5,444,500$ & $613,832,892$ & $0.89 \%$ \\
2017 & $62,248,789$ & $28,595,719$ & $217.69 \%$ \\
2018 & 0 & $24,396,980$ & $0.00 \%$ \\
2019 & $8,048,200$ & $2,576,300$ & $312.39 \%$ \\
\hline
\end{tabular}

Hasil perhitungan rasio jumlah treatment terhadap pasien tidak mampu yang disajikan pada tabel di atas menunjukkan angka yang beragam. Hal ini terjadi karena data laporan keuangan yang disajikan belum sepenuhnya menjawab kebutuhan data penelitian, sehingga perhitungan dilakukan secara manual dengan melihat mutasi debet-kredit pada neraca saldo pada account piutang non relasi. Belum melihat lebih dalam pada akun lain yang memungkinkan adanya transaksi pengurangan harga untuk pasien-pasien tidak mampu. Secara keseluruhan, hasil dari perhitungan rasio di atas dirangkum dalam tabel 8.

Tabel 8 menunjukkan hasil akhir rasio Maqashid Syariah Concordance (MSC) dari standar syariah yang diimplementasikan di Rumah Sakit Islam Sultan Agung, sebagai rumah sakit syariah. Hasil penilaian ini bisa digunakan oleh manajemen untuk melakukan perbaikan dalam implementasi syariah, terutama pada sisi Standar Syariah Manajemen Akuntansi dan Keuangan (SSMAK). 
Tabel 8. Rekapitulasi Rasio Maqashid Syariah Concordance Rumah Sakit Islam Sultan Agung

\begin{tabular}{|c|c|c|c|c|c|c|}
\hline $\mathbf{R a}$ & 2015 & 2016 & 2017 & 2018 & 2019 & \\
\hline 1. Keadilan & $.73 \%$ & $10.19 \%$ & $8.47 \%$ & & $3.57 \%$ & $7.84 \%$ \\
\hline 2. Keadilan & $15,13 \%$ & $0,00 \%$ & $9,38 \%$ & $23,08 \%$ & $9,23 \%$ & \\
\hline 3. Rek & & & & & & \\
\hline Syar & & & & & & \\
\hline karyawan & $0.37 \%$ & & & & & \\
\hline 5. Saldc & $0.00 \%$ & $0.00 \%$ & $72.30 \%$ & $0.15 \%$ & $0.40 \%$ & 14. \\
\hline $\begin{array}{l}\text { 6. kerja sama dengan bank } \\
\text { syariah }\end{array}$ & $30 \%$ & $50 \%$ & $50 \%$ & $56 \%$ & $56 \%$ & $48.40 \%$ \\
\hline $\begin{array}{l}\text { 7. treatment pasien tidak } \\
\text { mampu }\end{array}$ & $71.48 \%$ & $0.89 \%$ & $217.69 \%$ & $0.00 \%$ & $312.39 \%$ & $120.49 \%$ \\
\hline Rerata Capaian MSC / th & $48,38 \%$ & $50,00 \%$ & $53,13 \%$ & $59,69 \%$ & $55,08 \%$ & \\
\hline
\end{tabular}

\subsection{Quadrant Analysis Measurement (QAM)}

Bagian ini akan memberikan penjelasan mengenai posisi kesehatan rumah sakit syariah untuk setiap periode dalam bentuk kuadran. Quadrant Analysisi Measurement (QAM) ini dibentuk dari perbandingan angka profitabilitas rumah sakit, sebagai alat ukur kesehatan keuangan yang selama ini digunakan oleh rumah sakit dengan hasil rasio Maqashid Syariah Concordance (MSA), masing-masing diukur untuk rentang waktu satu periode. Angka profitabilitas yang digunakan untuk mewakili penghitungan rasio adalah Return on Investment (ROI) dan Return on Assets (ROA). Nilai ROI dan ROA Rumah Sakit Islam Sultan Agung selama kurun waktu yang diteliti tersaji di Tabel 9.

Tabel 9. Rekapitulasi Rasio Profitabilitas tahun 2015-2019 Rumah Sakit Islam Sultan Agung

\begin{tabular}{lrrrrr}
\hline \multicolumn{1}{c}{ Rasio } & $\mathbf{2 0 1 5}$ & $\mathbf{2 0 1 6}$ & $\mathbf{2 0 1 7}$ & $\mathbf{2 0 1 8}$ & \multicolumn{1}{c}{$\mathbf{2 0 1 9}$} \\
\hline ROA & $20.34 \%$ & $18.79 \%$ & $23.11 \%$ & $15.41 \%$ & $14.18 \%$ \\
ROI & $15.87 \%$ & $21.77 \%$ & $21.89 \%$ & $21.72 \%$ & $15.13 \%$ \\
Rerata Profitabilitas / th & $18.1 \%$ & $20.3 \%$ & $22.5 \%$ & $18.6 \%$ & $14.7 \%$ \\
\hline
\end{tabular}

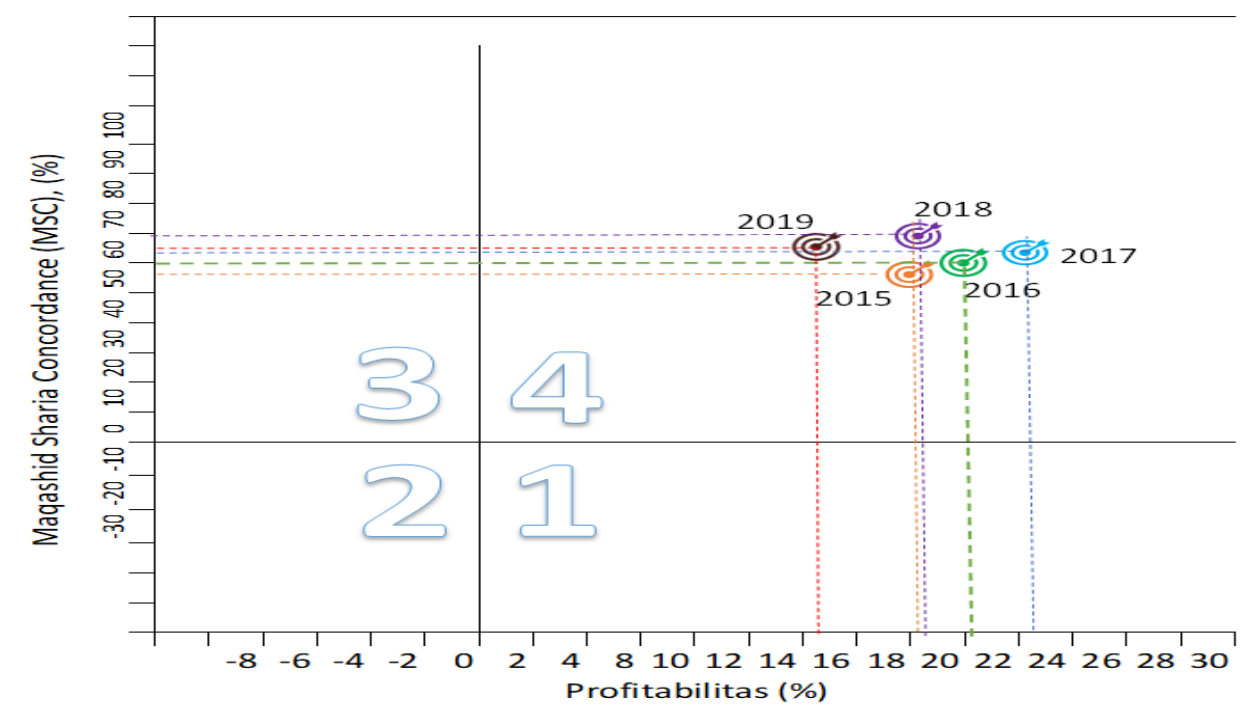

Gambar 1. Quadran Analysis Measurement (QAM) RSISA 2015-2019 
Quadran Analysis Measurement (QAM), berdasarkan rerata capaian MSC pada tabel 10 dan Rerata profitabilitas pada tabel 9 akan terlihat di gambar 1. Gambar 1 memperlihatkan posisi Rumah Sakit Islam Sultan Agung selama kurun waktu 5 (lima) tahun terakhir berada pada kuadran 4, yang menunjukkan kinerja profitabilitas baik, dan kinerja Maqashid Sharia Concordance (MSC) juga baik. Pada 2 tahun awal; 2015 - 2016 di mana Rumah Sakit Islam Sultan Agung belum ditetapkan sebagai Rumah Sakit Syariah, sedangkan 3 tahun berikutnya Rumah Sakit Islam Sultan Agung telah dikukuhkan sebagai rumah sakit syariah.

\section{SIMPULAN}

Rumah Sakit Islam Sultan Agung memiliki rasio rata-rata untuk keadilan anggaran yang menunjukkan porsi biaya dakwah dan sosial (daksos) dalam anggaran sangat baik, jika dibandingkan dengan nilai zakat mal sebasar 2.5\%. Sementara untuk Rasio Keadilan Tarif selama 5 tahun terakhir terungkap masih ada komplain dari dokter yang merasa tidak puas terhadap tarif rumah sakit. tarif baru (belum pernah ada) tidak termasuk dalam kriteria komplain. Perhitungan untuk Rasio Rekomendasi Komite Syariah tercapai $100 \%$, mengindikasikan peran komite syariah yang sudah sesuai dengan fungsinya. Rasio Saldo Dana ZIS menunjukkan perlu secara periodik pendistribusian ZIS dilakukan dengan membuat jadwal, sehingga tidak terjadi keterlambatan pendistribusian. Sementara Rasio Kerja Sama dengan Bank Syariah masih kecil proporsinya dibanding dengan bank konvensional, sehingga perlu didalami kembali beberapa alasan untuk mempertahankan kerja sama dengan bank konvensional yang masih ada. Hasil perhitungan Rasio treatment untuk pasien tidak mampu sama halnya dengan penyaluran ZIS, maka treatment terhadap pasien tidak mampu ini seharusnya terjadwal.

\section{REFERENSI}

Alhamid, Thalha. (2019). Perkembangan perbankan syariah (2009-2018) di Indonesia dan sumber daya manusianya. https://www.scribd.com/document/408369932/ARTIKEL-TALHAALHAMID-pdf

Faradiza, Sekar Akrom. (2018). Persepsi Keadilan, Sistem Perpajakan dan Diskriminasi Terhadap Etika Penggelapan Pajak. Akuntabilitas: Jurnal Ilmu Akuntansi Volume 11 (1), 2018: 53 - 74 P-ISSN: 1979-858X; EISSN: 2461-1190 DOI: 10.15408/akt.v11i1.8820

Hafidhuddin, Didin. 2002. Zakat dalam Perekonomian Modern, Jakarta: Gema Insani Press, hlm. 7.

Masyhudi AM. (2019). Tranformasi Ekonomi Syariah di Bidang Pelayanan Kesehatan (Rumah Sakit) dalam Menjawab Dinamika Perekonomian Global (Melalui Sertifikasi Rumah Sakit Syariah). Makalah disampaikan dalam Seminar Nasional Ikatan Akuntan Indonesia dengan tema "Mendukung Pembangunan SDM dan Transformasi Ekonomi Menuju Indonesia Emas 2045”, Jakarta, 6 Desember 2019

Muhamed \& Dzuljastri. (2008). The Performance Measures of Islamic Banking Based on the Maqasid Framework, IIUM International Accounting Conference INTAC IV Putra Jaya Marroit Malaysia.

Otoritas Jasa Keuangan (OJK). (2020). Statistik Perbankan Syariah (SPS).

Suharsimi, Arikunto. 2013. Prosedur Penelitian Suatu Pendekatan Praktik. Jakarta: Rineka Cipta 
Sulistiadi. Rahayu. (2016). Potensi Penerapan Maqashid Syariah Dalam Rumah Sakit Syariah di Indonesia, Batusangkar International Conference I, 15-16 October 2016

Susanti, Eva. Murnita, Syarifah. (2017). Analisis Kinerja Keuangan Pada Rumah Sakit Ibu Dan Anak Tahun Anggaran 2013-2015 Di Kota Banda Aceh. Jurnal Akuntansi Muhammadiyah Vol. 8 No. 1. ISSN :20879776

Wahid, Nisa Noor. Firmansyah, Irman. Fadillah, Adil Ridlo. (2018). Analisis Kinerja Bank Syariah Dengan Maqashid Syariah Index (MSI) Dan Profitabilitas. Jurnal Akuntansi Volume 13 (1) (Januari-Juni 2018) 19. ISSN: 1907-9958

Iit Septyaningsih. 2020. Potensi Industri Halal di Indonesia diniai masih besar. From https://www.republika.co.id/tag/industri-syariah diakses 30 Mei 2020

Jabbar, Abi Abdul. 2020. Mukisi Targetkan ada 100 RS Syariah Tersertifikasi di 2020. From https://www.madaninews.id/9544/mukisi-targetkanada-100-rs-syariah-tersertifikasi-di-2020.html diakses 30 Mei 2020

\section{LAMPIRAN}

Tabel 10. Rasio Kinerja Berdasar Buku Standar Akreditasi Rumah Sakit Syariah

\begin{tabular}{|c|c|c|c|c|}
\hline & Dimensi & $\begin{array}{c}\text { Rerata } \\
\text { Bobot }\end{array}$ & Indikator & $\begin{array}{l}\text { Rerata } \\
\text { Bobot }\end{array}$ \\
\hline \multirow[t]{9}{*}{1.} & \multirow[t]{9}{*}{$\begin{array}{l}\text { Tata kelola akuntansi dan } \\
\text { keuangan syariah }\end{array}$} & \multirow[t]{9}{*}{0,25} & $\begin{array}{l}\text { 1. Kebijakan tentang pengelolaan } \\
\text { keuangan sesuai kaidah } \\
\text { syariah }\end{array}$ & 0,127 \\
\hline & & & $\begin{array}{l}\text { 2. Pedoman/Panduan, dan } \\
\text { prosedur tata kelola akuntansi } \\
\text { dan keuangan syariah }\end{array}$ & 0,126 \\
\hline & & & 3. Rencana Kerja Anggaran & 0,127 \\
\hline & & & $\begin{array}{l}\text { 4. Rencana Kerja Anggaran yang } \\
\text { disusun, memenuhi prinsip } \\
\text { keadilan }\end{array}$ & 0,127 \\
\hline & & & 5. Menyusun Tarif & 0,124 \\
\hline & & & $\begin{array}{l}\text { 6. Tarif Rumah Sakit bersifat adil } \\
\text { bagi pasien, dokter, dan rumah } \\
\text { sakit }\end{array}$ & 0,127 \\
\hline & & & $\begin{array}{l}\text { 7. Rekomendasi dari Komite } \\
\text { Syariah terhadap kebijakan } \\
\text { yang diambil oleh rumah sakit }\end{array}$ & 0,118 \\
\hline & & & $\begin{array}{l}\text { 8. Menyusun Laporan keuangan } \\
\text { syariah }\end{array}$ & 0,125 \\
\hline & & & Jumlah & 1 \\
\hline \multirow{5}{*}{\multicolumn{2}{|c|}{$\begin{array}{l}\text { 2. Menjaga kesucian harta } \\
\text { dengan membayar zakat }\end{array}$}} & \multirow[t]{5}{*}{0,26} & $\begin{array}{ll}\text { 9. } & \text { regulasi pembayaran zakat } \\
\text { Institusi }\end{array}$ & 0,26 \\
\hline & & & $\begin{array}{l}\text { 10. regulasi pembayaran } \\
\text { infaq dan sadaqah } \\
\text { karyawan }\end{array}$ & 0,25 \\
\hline & & & $\begin{array}{l}\text { 11. Ada lembaga ZIS atau bekerja } \\
\text { sama dengan lembaga ZIS } \\
\text { yang resmi }\end{array}$ & 0,25 \\
\hline & & & $\begin{array}{l}\text { 12. Memiliki aturan penyaluran } \\
\text { ZIS }\end{array}$ & 0,24 \\
\hline & & & Jumlah & 1 \\
\hline & $\begin{array}{ll}\text { Menjaga kesucian harta } \\
\text { melalui kerja sama dg } \\
\text { Lembaga } & \text { Keuangan } \\
\text { Syariah } & \\
\end{array}$ & 0,24 & $\begin{array}{l}\text { 13. menjalin kerja sama dengan } \\
\text { bank syariah }\end{array}$ & 1 \\
\hline & & & Jumlah & 1 \\
\hline & \multirow{2}{*}{$\begin{array}{l}\text { Menjaga kesucian harta } \\
\text { dengan mengelola pasien } \\
\text { yang tidak mampu } \\
\text { membayar }\end{array}$} & \multirow[t]{2}{*}{0,25} & $\begin{array}{l}\text { 14. memiliki regulasi mengenai } \\
\text { Pasien yang tidak mampu } \\
\text { membayar }\end{array}$ & 0,33 \\
\hline & & & $\begin{array}{l}\text { 15. melakukan treatmen terhadap } \\
\text { pembayaran pasien yang tidak }\end{array}$ & 0,33 \\
\hline
\end{tabular}




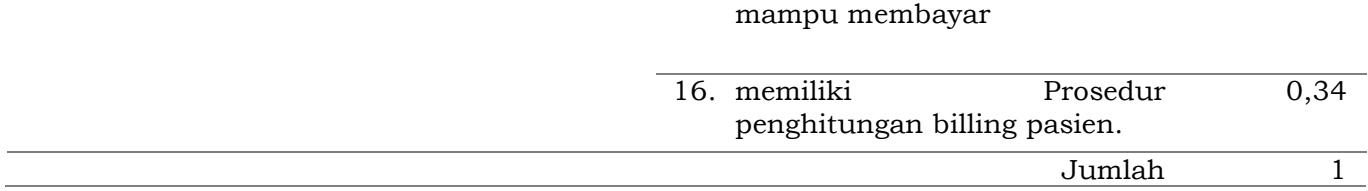

\section{Keterangan:}

Tabel 10 dibuat untuk memastikan bahwa semua dimensi dan indikator syariah yang ada di dalam SSMAK, diterima oleh khalayak. Dari 16 rasio yang disajikan di atas, hanya ada 7 rasio yang akan digunakan dalam menentukan kinerja Rumah Sakit Syariah, yaitu : 2 rasio pertama mengacu pada dimensi keuangan syariah pertama yaitu Tata kelola akuntansi dan keuangan syariah, 3 rasio yang kedua mengacu pada dimensi keuangan syariah kedua yaitu menjaga kesucian harta dengan membayar zakat, 1 rasio ketiga mengacu pada dimensi keuangan syariah ketiga yaitu menjaga kesucian harta melalui kerja sama dengan Lembaga Keuangan Syariah, dan 2 rasio terakhir mengacu pada dimensi keuangan syariah keempat, yaitu menjaga kesucian harta dengan mengelola pasien yang tidak mampu membayar. Sementara untuk indikator yang lain tidak dipergunakan karena ketujuh indikator yang dipilih, dianggap telah cukup mewakili.

Tabel 11. Indikator Rasio Maqashid Syariah Concordance (MSC)

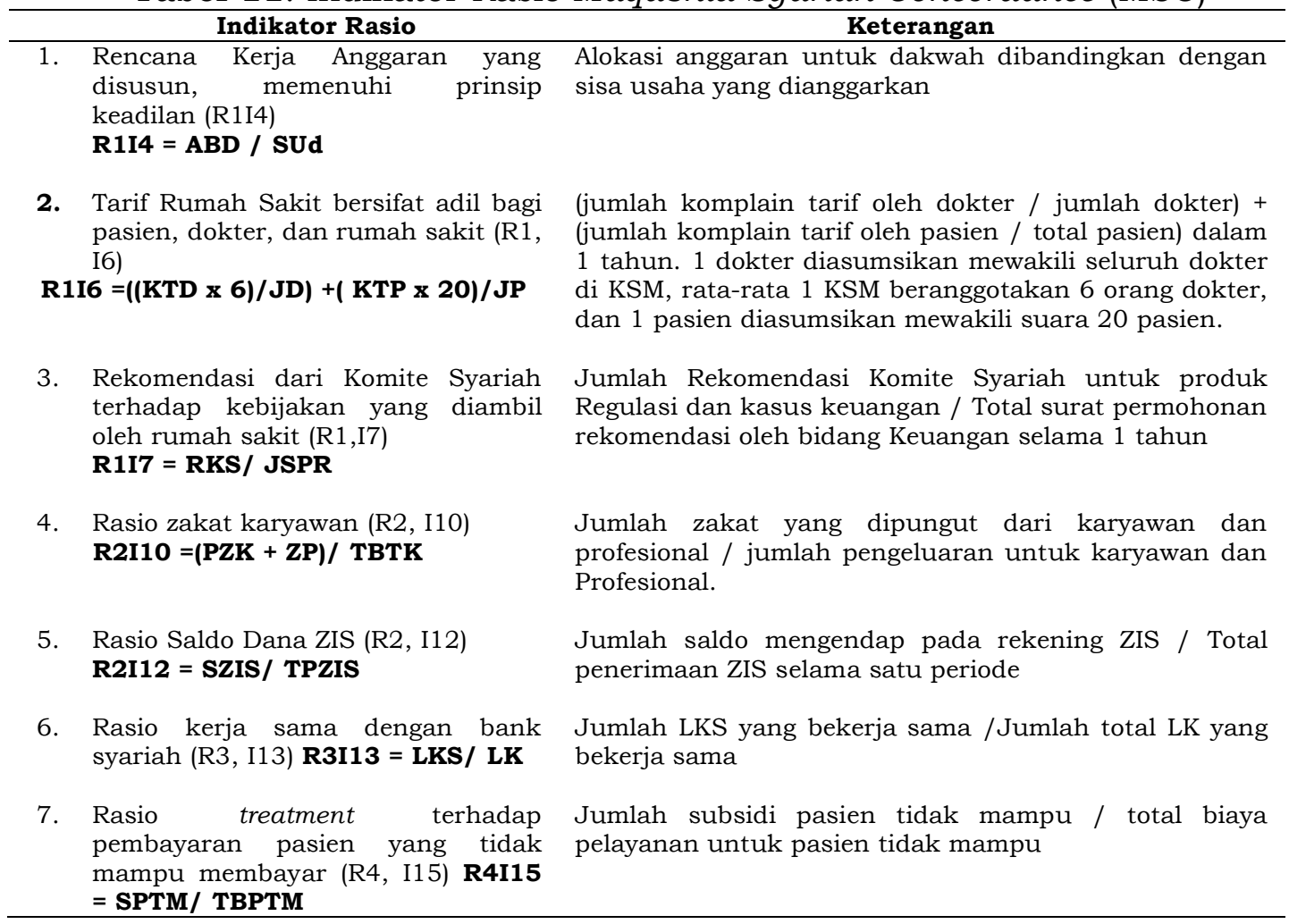

